\title{
FACTORS LEADING TO LIMITED RESEARCHES CONDUCTED BY PHILIPPINE PUBLIC SCHOOL TEACHERS
}

\author{
MARICEL A. GOMEZ ${ }^{*}$, MAURICIO M. CATAN ${ }^{2}$
}

${ }^{1}$ Leyte Normal University, P. Paterno, Tacloban City, Leyte, Philippines, 6500

${ }^{2}$ Department of Education-Leyte Division, Government Center, Palo, Leyte, Philippines

"Email: maricel.gomez@Inu.edu.ph

Received: 18 January 2021, Revised and Accepted: 19 February 2021

\begin{abstract}
The Department of Education (DepEd)- Leyte Division has conducted various activities to strengthen the research culture of the teachers. However, the number of teachers conducting action researches is still minimal despite efforts exerted by the office. Thus, this study was conducted to explore the reasons why teachers are having difficulty in doing research. Using content analysis as a design, this exploratory study revealed that the most common factors that prevent public school teachers from producing research include lack of time, lack of interest, lack of research expertise, overlapping activities, heavy teaching load, and limited financial support. This study helps raise awareness on the common issues expressed by the public-school teachers in the hope of starting some constructive discussion among DepEd officials on how to promote, sustain, and support the conduct of research studies. Some recommendations are made to help address more effectively the factors found in this study.
\end{abstract}

Keywords: Action research, Content analysis, Leyte, Public school, Public school teacher

(c) 2021 The Authors. Published by Innovare Academic Sciences Pvt Ltd. This is an open access article under the CC BY license (https://creativecommons.org/licenses/by/4.0/) DOI: https://dx.doi.org/10.22159/ijoe.2021v9i3.41272. Journal homepage: https://innovareacademics.in/iournals/index.php/ijoe

\section{INTRODUCTION}

The primary work of a classroom teacher is to transmit knowledge through teaching. However, as time changes, teachers now worked in a more complicated and dynamic system with lots of demands from them in their duty performance. Among the varieties of demands that a teacher has to meet is that of being able to conduct research Conducting research in the classroom is based on the premise that teachers are the ones that know exactly the current problems in the classroom. Addressing the existing classroom problems by the teachers makes them "become the catalysts for change and responsible agents for the improvement of their classroom teaching and uplifting student's learning" (Ulla, Barrera, \& Acompanado, 2017). Wolfe (1989) mentioned that "Teachers often leave a mark on their students, but they seldom leave a mark on their profession." But through the process and products of doing research, such as action research, teachers will be able to do both. "Teachers often leave a mark on their students, but they seldom leave a mark on their profession" (Johnson, 1993, p. 4).

In the Philippines, the conduct of research is no longer just being done by faculty and other people in the university or higher education institutions. At present, the importance of doing research in the public school system is becoming greatly recognized. The conduct of research is greatly encouraged among public school teachers in the elementary and secondary levels. The need to conduct research is reflected in the Basic Education Governance Act of 2001 created by the Department of Education (DepEd). The Act recognizes the great importance of research in the management and administration of the basic education system. The department's research thrusts are strategically geared towards supporting its mission "to protect and promote the right of every Filipino to quality, equitable, culture-based, and complete basic education..." (Department of Education, 2013a). It acknowledges the importance of research-based evidence as a basis for taking actions and decisions in ensuring the welfare and efficient learning of al students (Department of Education, 2016).

There are various efforts made by DepEd to strengthen the culture of research. These include the implementation of the Basic Education Research Agenda (BERA). BERA guides DepEd and its stakeholders in the conduct of education research and the utilization of research results in the planning, policy, and program development of the department (Department of Education, 2016). Included in the research agenda is a list of different themes that serve as priority research areas or topics that classroom teachers could focus on conducting research. These identified research topics are expected to generate results that will fill in critical knowledge gaps and improve the quality and delivery of basic education in the Philippines These are also consistent with the DepEd's mission and vision and with the local and international developments in the education sector, particularly the Sustainable Development Goals and Education 2030 (Department of Education, 2016).

Recognizing the importance of doing research, DepEd issued memoranda to ensure that public school teachers become actively involved in doing research. One of which is the DepEd Order 13, s. 2015, which establishes the policy development process requiring the use of evidence. The use of monitoring forms such as Individual Performance Commitment and Review Form (IPCRF) to gather evidence of teacher's research involvement was implemented. It is reflected in the IPCRF that one of the Major Final Outputs (MFO) for all teachers from teacher I to master teacher levels is the conduct of problem or classroom-based action research each year. The conduct of such is part of the standard expected outcome needed for a public school teacher to be promoted, as stated in DepEd Memorandum Order No. 42, series of 2007 (Morales et al., 2016).

In the Division of Leyte, various activities were initiated to establish a culture of research. The Division's Annual Accomplishment Report 2016 (Department of Education-Leyte Division, 2016) enumerated activities that were all aimed at empowering teachers to conduct research. These include conducted capability-building on research for teachers, master teachers, and school heads, provided technical assistance to teachers who wish to conduct research, organized research conferences, and carried-out monthly review of researches. However, despite these efforts of the department, there is still a high number of classroom teachers in Leyte who remain uninvolved in doing research. As per the record from Division's Annual Accomplishment Report 2016, out of 13,181 teachers, only 83 proposals and 13 completed papers were submitted to the division office (Department of Education-Leyte Division 2016). This dismal result proved that there are still severa 
teachers who do not acknowledge their potential of seeing themselves as researchers, and they are hesitant to write about their teaching practice or to participate in action research (Bondy, 2001; Hancock, 1997)

\section{REVIEW OF THE RELATED LITERATURE}

The different studies presented in this section focused on the concept of action research, the benefits of conducting action research, identified reasons for not doing action research, and the status of the conduct of action research in the Leyte Division.

\section{Action research}

The concept of action research has been mentioned in the first half of the twentieth century. It has been traced back to the early works of John Dewey in the 1920s and Kurt Lewin in the 1940s (Johnson, 1993). The term "action research" was coined by Lewin in 1946 with a vision to set an alternative to the customs of decontextualized research. According to Morales (2016), "instead of focusing on surveys and statistical methods, action research's purpose was to improve social formations by involving participants in a cyclical process of fact-finding, exploratory action, and evaluation." Lewin (1948) established the concept of action research with the aim of social change through improving the capacity and practices of the teacherresearcher rather than the production of theoretical knowledge (Morales et al., 2016). In 1949, Stephen Corey introduced the term action research in the educational community. He defined action researches as the "process through which practitioners study their own practice to solve their personal, practical problems" (Johnson, 1993). Since then, concepts of action research have expanded, making this type of investigation wellestablished.

Burns (2010) indicated that action research is centered on "reflective practice" and "teacher as researcher" identifying problems in their classroom and finding solutions to such issues. Becoming more reflective in teaching makes the teachers become researchers as they study themselves (McNiff, 2010). Ulla et al. (2017) further added that action research is all about teachers examining better ways to improve the current condition of their classroom setting and transforming it into what they believed to be better for the students. Similarly, some studies (Ado, 2013; Falk \& Blumenreich, 2005; Mills, 2003; Alber \& Nelson, 2002) indicated that the purpose of action research is to increase teacher's self-evaluation and reflectivity of their teaching practice, to understand, and enhance the quality of teaching and learning processes, thereby improving the lives of students (Johnson, 2012, p. 2).

\section{Benefits of action research}

There is a growing body of evidence indicating the positive effects of classroom teachers being involved in action research. Apart from improved reflectivity in their teaching practices (Morales, 2016; Morales et al., 2016; Bala, 2014; Ado, 2013; Johnson, 2012) other benefits that teachers experience on the conduct of action research as reflected in various literatures include the following: broadened and deepened understanding of their student's perspective in the classroom and their own teaching styles and strategies (Borg, 2014; Hong \& Lawrence, 2011; Burns, 2010) as they reflect on the result of their research studies (Ulla et al., 2017; McLaughlin, Black-Hawkins \& McIntyre 2004) improved teaching skills as they use bestresearched practices (Hine, 2013) contributed to professional development as they become better equipped with knowledge and skills while undergoing the rigor of doing action research(Ulla et al., 2017; Hine, 2013; Stewart, 2013; Mahani \& Molki, 2012; West, 2011; Cain \& Milovic, 2010) and becoming more responsible and accountable for the improvement and development of their teaching practices (Morales, 2016).

In addition, other studies indicated that action research acts as a catalyst toward effective change in the education process (Meerah, Johar, \& Ahmad, 2002). It enables teachers to find practical solutions to specific classroom problems (Bughio, 2015; Meerah et al., 2002). Likewise, Morales (2016) mentioned that conducting action research enhances collegiality or closer relationship among colleagues as they work collaboratively in the conduct of the research. It is also being pointed out by Johnson (2012) that action research bridges the gap between theory and practice making teachers conscious of the different aspects of the teaching process resulting in more effective and meaningful learning of the students. The benefits of conducting action research are al directed towards the improvement of the teacher as he/she becomes more sensitive and reflective of the current condition of the classroom. Being reflective will enable the teacher to find research-based solutions to various classroom problems, thereby making student's learning more effective and meaningful.

\section{Constraints of conducting action research}

Although there are quite a number of pieces of literature that pointed out the significance of conducting action research, there are also studies that brought forward factors that explain why there are still many classroom teachers who do not engage in conducting action research. In the Philippines, there are few studies conducted regarding this issue. But there are quite several studies in other countries that brought into light reasons why teachers do not involve in action research or any form of research. Even in early times, Darling-Hammond (1985) indicated that "teachers tend to misinterpret their role and capability as researchers of education. Teachers believe that research is the work of experts in education and that their work is to implement the results of research work in teaching." This view remains to be shared by some teachers at a more current time, as revealed in the study of Dehghan and Sahragard (2015). It was revealed in their study that the language teacher-participants viewed conducting research as not their duty as classroom teachers, but rather that of the professional researchers. Therefore, these teachers "neither do research nor use research in their own classrooms" (Ulla et al., 2017).

Lack of time is most frequently mentioned as a significant factor for not being able to conduct research (Morales et al., 2016; Vec and Rupar, 2015; Taskeen, Shehzadi, Khan, \& Saleem, 2014; Kutlay, 2012; Atay, 2006; Meerah et al., 2002; Hancock, 1997). Other references indicated that teachers do not conduct action research because they: do not see benefits of research on their work (Glanz, 2003; Educational Planning and Research Department, 1997), lack training and research skills (McDonough, 2006) and have difficulty in statistics (Burns, 2010). Furthermore, the Educational Planning and Research Division of the Ministry of Education of Malaysia in 1997 identified reasons for their teachers not motivated to conduct action research. These include lack of understanding and limited information on methods of action research, time constraint, heavy workload, lack of technical assistance, lack of support from administrators, lack of finance and facilities, failure of pre-service and in-service courses carried out by universities and teacher colleges to promote the importance of motivating teachers to do action research (Meerah et al., 2002). It can be seen from various literatures that there are varied reasons pointed out by teachers at various times why they are not motivated to do action research. In this study, the researchers explored the factors that still prevent public school teachers in the Leyte Division from conducting action research at the current time.

\section{Status of action research in the Leyte Division}

The Planning and Research Unit (PRU) of the Leyte Division is in charge of the policy and research activities of the Division in Leyte. This office of DepEd was created in 2015 as part of the implementation DepEd Rationalization Program (Department of Education, 2013b). One of its goals is to continuously conduct education research studies that serve as bases for necessary reforms and development. In Leyte Division, PRU was established in 2015. PRU- Leyte Division supervises 40 municipalities composed of 60 districts, 145 public high schools, 1,107 public elementary schools, and 13,181 public school teachers (Planning and Research Unit, 2016). A significant number of teachers are expected to do action research every year. But it was recorded that in 2016, only 83 
proposals and 13 completed papers were submitted to the office.

Furthermore, Leyte Division initiated a research conference in 2016 and invited all research enthusiasts to submit their completed researches for the competition. However, only a few teachers heeded the call with seven (7) action researches and six (6) basic researches presented during the conference. The basic studies were the theses and dissertations of teachers in their respective graduate schools PRU (2016). These statistics showed the lack of involvement of teachers in action research, despite that conducting action research comprises five percent of the total score in the individual teacher's evaluation and one of the major outputs in their yearly IPCRF (Department of Education, 2016)

\section{STATEMENT OF THE PROBLEM}

There is a limited number of studies exploring in local context the factors that make the DepEd public school teachers are still not motivated to conduct action research. It is the purpose of this paper to explore those factors to fill that gap in the existing literature. The results of this may serve as a basis for designing practical steps to be done by DepEd officials to address the factors identified, thereby encouraging more public-school teachers to take an active role in being a researcher.

\section{OBJECTIVES}

The purpose of the study was to identify the factors that prevent public school teachers from conducting research. The study also provides recommendations on how to address the factors identified to encourage public school teachers to become more active in conducting research to improve the quality of education.

\section{RESEARCH QUESTION}

The study sought to find the answer to this question: What are the factors that prevent public school teachers from conducting research?

\section{METHODOLOGY}

\section{Research design}

In this study, content analysis was used as the main design to be able to bring into the light and understand the factors that prevent public classroom teachers from doing action research or other forms of research. The procedure is patterned from a similar study conducted by Wa-Mbaleka (2015) on identifying factors that prevent college and university faculty from publishing. Since this study has no predetermined variables, a conventional content analysis design, as proposed by Hsieh and Shannon (2005), was employed. This design is applicable because "it allows the researchers to use an inductive approach to data analysis when data has no predetermined variables or theories" (Wa-Mbleka, 2015). It was the primary focus of this study to identify the variables that prevent public classroom teachers from doing action research or any form of research. Research setting

This study was based on qualitative data collected from public school teachers who participated in the Division Research Conference last September 29-30, 2016. The teachers came from different parts of the Leyte Division. The Research Conference was a competition of both oral and poster presentations of varying master's thesis, dissertations, and few action researches conducted by public elementary and high school teachers. The attendance sheet of the conference was used to determine the participants of the study.

Sample and sampling

A total of 265 public school teachers attended the Division Research Conference. All the participants were targeted. However, only a total of 175 public school teachers, composed of 83 elementary and 92 high school teachers coming from the different schools under the Leyte Division, participated in the study and answered the one-page questionnaire.

\section{Data collection}

Using the attendance sheet of the Division Research Conference, days after the conference, a one-page questionnaire was sent to the participants to answer. Aside from some demographic information requested, participants were asked only one question that is to write three reasons that prevent them from writing action research or any other form of research. Informed consent was sought from the participants. They were informed that their responses will be used as a basis for the PRU for deciding on the steps to be taken to strengthen the active involvement of teachers in doing action research. They were ensured of the confidentiality of the information they provided and that data will be reported collectively. Since the instrument was made of only one question to elicit reasons why DepEd teachers were not able to make action research or other forms of research, validation of the instrument was not necessary (Wa-Mbaleka, 2015).

Data analysis

Analysis of the data was patterned from the study of WaMbaleka (2015). Manifest analysis, word or theme count, and latent analysis, or use of underlying meaning as proposed by (Thayer, Evans, McBride, Queen, \& Spyridakis, 2007) were employed. Some responses of the participants were clearly stated, such as lack of time, lack of interest, which easily identified as factors using manifest analysis. However, some other data were needed to be carefully examined for their underlying meaning, which then required latent analysis (WaMbaleka, 2015). For example, a response "I am not so acquainted yet of the steps" was interpreted and coded as "lack of research knowledge."

\section{RESULTS}

Findings from the survey questionnaire with regards to participant's demographics and different factors identified by the participants with regards to not being able to conduct research are presented here.

\section{Participant's demographics}

There were 54 male and 121 female participants in the study. The majority of the participants or 68 participants were in the 51-60 years old age range, followed by $41-50$ years old (62 participants), 31-40 years old (28 participants) and 20-30 years old (17 participants). There were 70 participants who have master's degree units, 36 completed a master's degree, 31 with doctorate units, 26 with doctorate degrees, and 12 with only bachelor's degrees yet. In terms of the number of years in service, 71 of the participants were 21-30 years in service, 38 participants were 11-20 years, 30 participants were 1-10 years, and 29 participants were 31-40 years in service. Factors preventing teachers from conducting research This portion presents the results of the survey conducted regarding the reasons why teachers are not able to work on action research. About 175 respondents were grouped into two; Group A was composed of elementary school teachers and group B were high school teachers. There were ten (10) factors identified by participants, and these are presented in Table 1.

Table 1: Factors that prevents teachers from doing research

\begin{tabular}{|l|c|c|c|}
\hline \multirow{2}{*}{\multicolumn{1}{|c|}{ Factors }} & \multicolumn{2}{|c|}{$\begin{array}{c}\text { Number of } \\
\text { responses }\end{array}$} & \multirow{2}{*}{ Total } \\
\cline { 2 - 3 } & $\begin{array}{c}\text { Group } \\
\text { A }\end{array}$ & $\begin{array}{c}\text { Group } \\
\text { B }\end{array}$ & \\
\hline Lack of time & 80 & 65 & 145 \\
\hline $\begin{array}{l}\text { Lack of knowledge in conducting } \\
\text { research }\end{array}$ & 40 & 35 & 75 \\
\hline Lack of training & 25 & 30 & 55 \\
\hline Lack of technical assistance & 18 & 19 & 37 \\
\hline Limited funding and resources & 15 & 14 & 29 \\
\hline Lack of interest & 4 & 11 & 15 \\
\hline Difficulty in choosing a topic & 2 & 4 & 6 \\
\hline $\begin{array}{l}\text { Lack of confidence in English } \\
\text { writing }\end{array}$ & 3 & 2 & 5 \\
\hline Fear of rejection & 2 & 2 & 4 \\
\hline Poor health condition & 2 & 2 & 4 \\
\hline
\end{tabular}




\section{DISCUSSION}

\section{Lack of time}

Table 1 shows that 145 of the participants considered a lack of time as the primary factor for not being able to conduct action research or any form of research. This factor remains to be the primary constraint in conducting action research for teachers confirming the findings of previous studies (Morales et al., 2016; Vec and Rupar, 2015; Taskeen et al., 2014; Kutlay, 2012; Atay, 2006; Meerah et al., 2002, Hancock, 1997). This factor may be the underlying factor of all the difficulties identified. The mandate of the Civil Service Commission is an eight-hour rendition of services in the school, six (6) hours of which is to be spent for actual classroom teaching while the remaining two (2) hours will be for other activities, which could either be spent inside or outside the school premises (Lapus, 2009). Teachers have a heavy workload that includes many papers works to accomplish every day, which they work on during their vacant periods falling under the two-hour allotment for curricular tasks. In addition, teachers have to work on their daily lesson plans, check papers, compute grades, and submit reports on their special assignments. Another set of activity which teachers undertake is the conduct of remedial or enrichment classes as well as other tasks instrumental in developing student's well-being. In addition, teachers with master's and doctorate units or degrees are usually given administrative functions, leaving them not enough time to do research. Given the heavy workload and demanding nature of their profession, it is understandable that teachers may have little time and energy left to conduct quality research. By giving teachers a considerable number of hours for teaching and conducting research, they will be able to deliver their work more effectively and efficiently.

Lack of knowledge in the conduct of an action research

The second major factor identified by around 75 participants is the lack of knowledge in conducting research. Teacher's viewpoint on lack of expertise encompassed their inability to write the complete parts of the action research.

In the study conducted by Morales (2016) and colleagues, they found out that teachers have a moderate level of difficulty in carrying out action research. This is interesting to note since teachers are exposed to different types of research work in their graduate studies and even at the undergraduate level. With 13,181 public school teachers in DepEd-Leyte Division in 2016, it is expected that there will be a great number of action research outputs every year. However, based on the Division's Annual Accomplishment Report 2016, only 83 proposals and 13 completed papers were submitted to the DepEd-Leyte Division Office (Department of Education-Leyte Division, 2016). This is a very low number of research outputs compared to the number of teachers in the Division.

In addition, teachers may find the cyclical steps of the action research process difficult to follow. The full conduct of action research is not within a snap of a finger. Several scholarly steps need to be followed, which teachers should be familiar with. This situation may indicate that teachers have a problem in making action research, a situation warranting a suitable development plan by educational authorities. Although teachers may have a knowledge background in conducting action research, they needed continuous further support to enhance their research knowledge and skills.

\section{Lack of training}

Around 55 of the participants indicated that their lack of training in the conduct of action research prevents them from doing such research. This result is in parallel to the finding of McDonough (2006). Teachers clamour for more training or workshops to make them more adept in the conduct of such type of research. Training on action research is of paramount importance so that teachers will be able to enhance their knowledge and polish their skills on how to carry out investigations successfully addressing problems in the local classroom setting while teaching. Sheikh et al. (2013) posited that workshops, seminars and training create positive effects among teachers who are pursuing research studies. Hence, teachers must be given opportunities to be exposed to research training, workshops, and conferences, to develop more of their skills and to conduct a research project on their own confidently.

\section{Lack of technical assistance}

The fourth factor identified by around 37 of the participants identified the lack of technical assistance in conducting action research, making it a barrier in carrying out such scholarly endeavour. This result is a similar finding to the study of Meerah et al. (2002). Even if teachers are sent to attend seminars on action research, the application of knowledge gained will be made more evident if they are guided by an authority or an expert upon school implementation of the action research. In other words, technical assistance will strengthen the application of concepts to the actual conduct of action research.

\section{Limited funding and resources}

There were 29 participants who indicated that they have an interest in carrying out action research, but what hinders them in pursuing it is having limited funds and resources. This finding is similarly reflected in the study of Meerah et al. (2002). Along the way, in the conduct of action research, materials need to be developed, supplies need to be purchased, and internet connectivity needs to be secured. All these entail the need for funding. The salary that teachers received may not be enough to personally fund the needs of the successful conduct of such research.

Lack of interest

Fifteen of the participants indicated that they do not conduct action research simply because they lack interest in doing it. This lack of interest may be explained by what the literature has shown that these teachers may be viewed conducting research as not their duty as classroom teachers, but rather that of the professional researchers. Therefore, these teachers "neither do research nor use research in their own classrooms" (Ulla et al., 2017). This may also be because teachers do not see the benefits of research on their work (Glanz, 2003; Educational Planning and Research Department, 1997). In addition, according to Meerah et al. (2002) the "failure of preservice and in-service courses conducted by universities and teacher colleges to promote the importance of motivating teachers to conduct action research" may contribute to the few numbers of teachers engaging in action research.

\section{Difficulty in choosing a topic}

One of the hardest aspects of research is choosing a topic. Six (6) of the participants had indicated that what hampers them from conducting action research is they find it challenging to select a research topic that they can work on. Ironically, included in the Research Agenda of DepEd is a list of different themes that serve as priority research areas or issues that classroom teachers could focus on conducting research. These teachers need assistance to help them identify possible research topics that they can work on further to improve the current conditions of the teaching-learning process.

\section{Lack of confidence in English writing}

Research writing is a challenging task since this entails scholarly work where the coherence of ideas on the topic and results needs to be presented. Knowledge and skills in English writing is a tool; therefore, to come up with sound research output. Around five (5) of the participants indicated their lack of confidence in English writing prevents them from conducting research. Although this is a small number, the fact remains that there are still teachers who need training on the improvement of their English writing skills.

\section{Fear of rejection}

Four (4) participants have indicated that their fear of rejection of the action research proposal submitted does not motivate them to conduct research. Teachers provide a research proposal to the DepEd Research and Planning Office before the actual conduct of the study. This process is needed to assess the quality and authenticity of the research that is to be conducted submitted. It is also a way to provide technical assistance to the researcher. But their fear of rejection does not motivate them to engage in conducting action research. It 
should be noted that the rejection of a proposal should never stop them from working on action researches since they will learn from the comments of the evaluators on how they can improve the output for future researches.

Poor health condition

Teaching is demanding in nature and entails a heavy workload. It is not surprising that teachers become stressed and lead to the poor health condition. This fact supports four (4) of the participants who emphasized that poor health condition is a factor that hinders them from working on action researches. It is interesting to note that those who indicated poor health conditions were in the age range of 51 to 60 years old and 31 to 40 years in service. Their extended service may have led to their poor health condition, making them not motivated to do any other demanding task such as conducting research.

\section{Recommendations}

The identified factors which were considered as hindrances by the teacher-respondents in the conduct of action research can be provided with proposed solutions presented in Table 2 .

Table 2: Proposed solutions of factors or variables that prevent teachers from doing research

\begin{tabular}{|c|c|}
\hline Factors/variables & Proposed solutions \\
\hline Lack of time & De-Loading, crafted unified school activities, hiring clerical position \\
\hline Lack of knowledge & $\begin{array}{l}\text { Conduct training and mentoring on research, provide research } \\
\text { guide handbook, publish research journals quarterly }\end{array}$ \\
\hline Lack of training & $\begin{array}{l}\text { Conduct school-based training on research, action research } \\
\text { colloquium, hold research fora for teachers, school heads and } \\
\text { supervisors }\end{array}$ \\
\hline Lack of technical assistance & $\begin{array}{l}\text { Train school heads on how to conduct action research, organization } \\
\text { of action research team per school and district }\end{array}$ \\
\hline Limited funding and resources & $\begin{array}{l}\text { Inclusion of action research in the school improvement plan, } \\
\text { endorse more proposals for BERF funding }\end{array}$ \\
\hline Lack of interest & $\begin{array}{l}\text { Close monitoring of action research implementation, strengthen } \\
\text { technical assistance provision }\end{array}$ \\
\hline Lack of confidence in English writing & $\begin{array}{l}\text { Conduct of capacity building seminars on technical writing, } \\
\text { coordinate with CID supervisor in English for a relevant training }\end{array}$ \\
\hline Difficulty in choosing a topic & $\begin{array}{l}\text { Organization of research/lesson study group, create an FB page } \\
\text { where teachers can freely exchange ideas }\end{array}$ \\
\hline Fear of rejection of the action research proposal submitted & Strengthen action research committees in school and the district \\
\hline Poor health condition & Conduct of quarterly stress-removal activities \\
\hline
\end{tabular}

\section{CONCLUSION}

There are ten factors identified that prevent public school teachers in DepEd from conducting action research. These factors include lack of time, lack of knowledge in conducting research, lack of training, lack of technical assistance, limited funding and resources, lack of interest, lack of confidence in English writing, difficulty in choosing a topic, fear of rejection of the action research proposal submitted, and poor health condition. Encouraging more active involvement of teachers in action research requires the cooperative efforts of both the DepEd and the individual teacher. DepEd should continue to provide initiatives and continue to support classroom teachers in order to encourage them to become proactive in doing action research.

\section{ACKNOWLEDGEMENT}

The researchers would like to thank the Department of Education-Leyte Division for allowing the data gathering of the study.

\section{AUTHORS CONTRIBUTIONS}

The authors of the study had worked collaboratively in all aspects of the research from the data gathering, data analysis, and manuscript preparation.

\section{CONFLICT OF INTEREST}

The researchers declare no conflict of interest in the conduct of this study.

\section{FUNDING SOURCE}

There is no funding agency.

\section{REFERENCES}

- Ado, K. (2013). Action research: Professional development to help support and retain early career teachers. Educational Action Research, 21(2), 131-146. doi.org/10.1080/09650792.2013.789701

- $\quad$ Alber, S. R., \& Nelson, J. S. (2002). Putting research in the collaborative hands of teachers and researchers: An alternative to traditional staff development. Rural Special Education Quarterly, 21(2), 24-32. doi.org/10.1177/875687050202100104

- Atay, D. (2006). Teacher's professional development: Partnerships in research. TESL-EJ, 10(2). Retrieved from http://www.teslej.org/wordpress/issues/volume10/ej38/ej38a8/

- Bala, R. (2014). Teacher as researcher. International Journal of Research in Social Sciences and Humanities. 3(2). 10-16. Retrieved from http://www.ijrssh.com/images/short_pdf/Oct_2014_DR. \%20RAJNI\%20BALA\%20Dec\%202.pdf

- Bondy, S. (2001). Warming up to classroom research in a professional development school. Contemporary Education, 72(1), 8-6.

- Borg, S. (2014). Teacher research for professional development. In G. Pickering \& P. Gunashekar (Eds.), Innovation in English Language Teacher Education Selected papers from the fourth International Teacher Educator Conference, Hyderabad, India (pp. 23-28). New Delhi, India: British Council

- Burns, A. (2010). Doing action research- what's in it for teachers and institutions? International House Journal of Education and Development, (29). 3-6. Retrieved from http://ihjournal.com/ doing-action-research$\%$ e2\%80\%93-what $\%$ e2\%80\%99s-in-it-for-teachers-and institutions-by-anne-burns 
- $\quad$ Cain, T., \& Milovic, S. (2010). Action research as a tool of professional development of advisers and teachers in Croatia. European Journal of Teacher Education, 33(1), 19-30. doi.org/10.1080/02619760903457768

- Corey, S. M. (1953). Action research to improve school practice. New York, USA: Bureau of Publications, Teachers College, Columbia University.

- Darling-Hammond, L. (1985). Valuing teachers; The making of a professional. Teachers College Record, 87(2), 205-218. Retrieved from https://www.tcrecord.org

- Dehghan, F., \& Sahragard, R. (2015). Iranian EFL teacher's views on action research and its application in their classrooms: A case study. Journal of Teacher Education and Educators, 4(1), 39-52. Retrieved from http://itee.org/document/issue7/MAKALE\%203.pdf

- Department of Education. (2016). Adoption of the basic education research agenda (DepEd order memo no. 39, s. 2016). $\quad$ Retrieved from https://www.deped.gov.ph/2016/06/10/do-39-s-2016adoption-of-the-basic-education-research-agenda/

- Department of Education. (2015). New organizational structures of the central, regional, and schools division offices of the Department of Education (DepEd Memo Order No. 52, s 2015). Retrieved from https://www.deped.gov.ph/2015/10/30/do-52-s-2015new-organizational-structures-of-the-central-regionaland-schools-division-offices-of-the-department-ofeducation/

- Department of Education. (2013a). Our Department of Education vision, mission and core values (DepEd Order Memo Order No. 36, s. 2013). Retrieved from https://www.deped.gov.ph/2013/09/04/do-36-s-2013our-department-of-education-vision-mission-and-corevalues-deped-vmv/

- Department of Education. (2013b). Approval and implementation of the 2013 DepEd rationalization program (DepEd Order No. 53). Retrieved from https://www.deped.gov.ph/2013/12/03/do-53-s-2013approval-and-implementation-of-the-2013-depedrationalization-program/

- Department of Education-Leyte Division. (2016). Division's annual accomplishment report 2016. Palo, Philippines: DepEd-Leyte Division.

- $\quad$ Educational Planning and Research Department. (1997) Program for innovation, excellence and research (PIER) (1993-1996) Report. Kuala Lumpur, Malaysia: Ministry of Education.

- Falk, B., \& Blumenreich, M. (2005). The power of questions: A guide to teacher and student research. Portsmouth, New Heinemann: Heinemann Educational Books.

- Glanz, G. (2003). Action research: An educational leader's guide to school improvement (2nd ed.). Massachusetts, New England: Christopher-Gordon Publishers, Inc.

- Hancock, R. (1997). Why are class teachers reluctant to become researchers? Journal of In-Service Education, 23(1),

85-99. doi.org/10.1080/13674589700200009

- $\quad$ Hine, G. S. C. (2013). The importance of action research in teacher education programs. Issues in Educational Research, 23(2), 151-162. Retrieved from http://www.iier.org.au/iier23/hine.pdf

- Hong, C. E., \& Lawrence, S. A. (2011). Action research in teacher education: Classroom inquiry, reflection, and data-driven decision making. Journal of Inquiry \& Action in Education, 4(2), 1-17. Retrieved from http://www.wpunj.edu/dotAsset/330733.pdf

- Hsieh, H.-F., \& Shannon, S. E. (2005). Three approaches to qualitative content analysis. Qualitative Health Research, 15(9), 1277-1288. doi.org/10.1177/1049732305276687

- Johnson, A. P. (2012). A short guide to action research (4th ed.). New Jersey: Pearson.
- Johnson, B. (1993). Teacher-as-researcher. ERIC digest. Retrieved from http://files.eric.ed.gov/fulltext/ED355205.pdf

- Kutlay, N. (2012). A survey of English language teacher's views of research. Procedia-Social and Behavioral Sciences. 70, 188-206. doi.org/10.1016/i.sbspro.2013.01.055

- Lapus, J. A. (2009). Guidelines for the Implementation of CSC Resolution No. 080096 on Working Hours for Public School Teachers. Pasig City, Philippines: Department of Education. $\quad$ https://www.deped.gov.ph/wpcontent/uploads/2018/10/D0 s2009 16.pdf

- Mahani, S., \& Molki, A. (2012). Enhancing the quality of teaching and learning through action research. Journal of College Teaching \& Learning (TLC), 9(3), 209-216. doi.org/10.19030/tlc.v9i3.7086

- McDonough, K. (2006). Action research and the professional development of graduate teaching assistants. The Modern Language Journal, 90(1), 33-47. doi.org/10.1111/j.1540-4781.2006.00383.x

- $\quad$ McLaughlin, C., Black-Hawkins, K., \& McIntyre, D. (2004). Researching teachers, researching schools, researching networks: A review of the literature. Retrieved from https://www.educ.cam.ac.uk/research/programmes/sup er/ReviewOfLiterature.pdf

- McNiff, J. (2010). Action research for professional development: Concise advice for new and experienced action researchers. Dorset: September Books.

- Meerah, T. S. M., Johar, A. R., \& Ahmad, J. (2002). What motivates teachers to conduct research? Journal of Science and Mathematics Education in S.E. Asia, 15(1), 1-24.

- Mills, G. (2003). Action research: A guide for the teacher researcher. Upper Saddle River: Pearson Education, Inc.

- Morales, M. P. E. (2016). Participatory action research (PAR) cum action research (AR) in teacher professional development: A literature review. International Journal of Research in Education and Science, 2(1), 156-165.

- $\quad$ Morales, M. P. E., Abulon, E. L. R., Soriano, P. R., David, A. P., Hermosisima, M. V. C., \& Gerundio, M. G. (2016) Examining teacher's conception of and needs on action research. Issues in Educational Research, 26(3), 464-482.

- $\quad$ Planning and Research Unit. (2016). Teacher's researches records 2016. Department of Education. Leyte Division.

- Sheikh, A. S. F., Sheikh, S. A., Kaleem, A., \& Waqas, A. (2013). Factors contributing to lack of interest in research among medical students. Advances in Medical Education and Practice, 4, 237-243. doi.org/10.2147/AMEP.S51536

- Stewart, T. (2013). Classroom research and classroom teachers. FLLT conference proceedings, Language Institute of Thammasat University, Bangkok, Thailand. Retrieved from

http://www.litu.tu.ac.th/journal/FLLTCP/Proceeding/134.pdf

- $\quad$ Taskeen, S., Shehzadi, A., Khan, T., \& Saleem, N. (2014). Difficulties faced by novice researchers: A study of universities in Pakistan. International Journal of Art and Literature, 1(1), 1-4. Retrieved from http://www.openscienceonline.com/journal/archive2?jo urnalId=702\&paperId=338

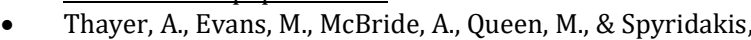
J. (2007). Content analysis as a best practice in technical communication research. Technical Writing and Communication, 37(3), 267-279. doi.org/10.2190/TW.37.3.c

- Ulla, M. B., Barrera, K. I. B., \& Acompanado, M. M. (2017) Philippine classroom teachers as researchers: Teacher's perceptions, motivations, and challenges. Australian Journal of Teacher Education, 42(11). 51-64. doi.org/10.14221/ajte.2017v42n11.4

- Vec, T. R., \& Rupar, B. (2015). Evaluation of teacher's perceptions of action research process effects: What leadership style is appropriate for the implementation of change in schools? National Education Institute, Slovenia. 
- Wa-Mbleka, S. (2015). Factors leading to limited faculty publications in Philippine higher education institutions. International Forum, 18(2), 121-141.
- West, C. (2011). Action research as a professional development activity. Arts Education Policy Review, 112(2), 89-94. doi.org/10.1080/10632913.2011.5466 